\title{
Gastrointestinal parasites in feral cats and rodents from the Fernando de Noronha Archipelago, Brazil
}

\author{
Parasitos gastrointestinais em gatos ferais e roedores do Arquipélago de Fernando de Noronha, Brasil \\ Victor Fernando Santana Lima ${ }^{1 *}$; Rafael Antonio Nascimento Ramos ${ }^{2}$; Raphael Lepold ${ }^{1}$; João Carlos Gomes Borges ${ }^{3}$; \\ Carlos Diógenes Ferreira ${ }^{4}$; Laura Rinaldi ${ }^{5}$; Giuseppe Cringoli ${ }^{5}$; Leucio Câmara Alves ${ }^{1}$ \\ ${ }^{1}$ Departamento de Medicina Veterinária, Universidade Federal Rural de Pernambuco - UFRPE, Recife, PE, Brasil \\ ${ }^{2}$ Unidade Acadêmica de Garanhuns, Universidade Federal Rural de Pernambuco - UFRPE, Garanhuns, PE, Brasil \\ ${ }^{3}$ Fundação Mamíferos Aquáticos, Recife, PE, Brasil \\ ${ }^{4}$ Coordenadoria de Meio Ambiente, Administração do Arquipélago de Fernando de Noronha, PE, Brasil \\ ${ }^{5}$ Dipartimento di Medicina Veterinaria e Produzioni Animali, Università degli Studi di Napoli Federico II, Napoli, Italia
}

Received August 7, 2017

Accepted October 19, 2017

\begin{abstract}
Gastrointestinal parasites are important pathogens affecting animals, some of them are of medical and veterinary concern. Although the dynamic of parasitic infections is a complex phenomenon that has been studied under experimental conditions, it shows several gaps in knowledge, especially in insular regions where a confined population of animals and parasites co-exists. In this study was assessed the parasitism by endoparasite gastrointestinal in feral cats $(\mathrm{n}=37)$ and rodents $(\mathrm{n}=30)$ from the Fernando de Noronha Archipelago; in addition, the risk of human infection and ecological implications of these findings were discussed. Out of all samples analysed, $100 \%$ scored positive for the presence of gastrointestinal parasites in both feral cats and rodents. A total 17 genera and/or species of endoparasite gastrointestinal were identified, Ancylostoma sp., Strongyloides sp., Trichuris campanula and Toxocara cati were the parasites more frequently in feral cats. In rodents Eimeria sp., Strongyloides sp. and Trichuris muris were parasites more frequently herein detected. Human population living in this area are at risk of parasite infections due to the population of rodents and feral cats in the archipelago.
\end{abstract}

Keywords: Helminths, protozoal disease, zoonosis, synanthropic animals.

\section{Resumo}

Parasitas gastrointestinais são importantes agentes patogênicos que afetam os animais, sendo alguns destes de interesse médico e veterinário. Embora a dinâmica das infecçóes parasitárias seja um fenômeno complexo que tem sido estudado sob condiçóes experimentais, existem várias lacunas no conhecimento, especificamente em regióes insulares onde existem populaçóes confinadas de animais e parasitas. Neste estudo foi avaliado o parasitismo por endoparasitas gastrointestinais em gatos ferais $(n=37)$ e roedores $(n=30)$ do Arquipélago de Fernando de Noronha. Além disso, discutiu-se o risco de infecção humana e implicaçóes ecológicas desses achados. De todas as amostras analisadas, 100\% obtiveram resultados positivos para a presença de parasitos gastrointestinais tanto em gatos ferais quanto em roedores. Um total de 17 gêneros e/ou espécies de endoparasitos gastrointestinais foram identificados, Ancylostoma sp., Strongyloides sp., Trichuris campanula e Toxocara cati foram os parasitos mais frequentes em gatos ferais. Em roedores Eimeria sp., Strongyloides sp. e Trichuris muris foram os mais detectados. A população humana que vive nesta área corre o risco de infecçôes parasitárias, devido à população de roedores e gatos ferais no arquipélago.

Palavras-chave: Helmintos, doenças protozoárias, zoonoses, animais sinantrópicos.

*Corresponding author: Victor Fernando Santana Lima. Departamento de Medicina Veterinária, Universidade Federal Rural de Pernambuco - UFRPE, Rua Dom Manoel de Medeiros, s/n, Dois Irmãos, CEP 52171-900, Recife, PE, Brasil. e-mail: victor.fslima@gmail.com 


\section{Introduction}

Gastrointestinal parasites are important pathogens affecting animals and humans throughout the world (BLAGBURN et al., 1996; DEPLAZES et al., 2016). According to the World Health Organization (WHO), approximately 3.5 billion of people are affected by these parasites every year, being 450 million children who present clinical manifestations (OKYAY et al., 2004). Among animals, cats and rodents are considered important reservoirs for a wide range of zoonotic parasites. For example, cats may harbour several species of gastrointestinal parasites (e.g., Ancylostoma tubaeforme, A. brasiliensis, Toxocara cati and Toxoplasma gondii), and shed their immature stages through the faeces, contaminating the environment (BALASSIANO et al., 2009; COSTA et al., 2012; BEUGNET et al., 2014; MONTEIRO et al., 2016; SARAVANAN et al., 2016).

Similarly, rodents may represent an important risk for human beings as involved in the transmission of different pathogenic agents, including gastrointestinal parasites (e.g., Giardia duodenalis and Hymenolepis diminuta) (BACKHANS et al., 2013; LÓHMUS \& ALBIHN, 2013; DEPLAZES et al., 2016). Amongst the most relevant are $A$. tubaeforme, $A$. brasiliensis and $T$. cati, causative agents of Cutaneous and Visceral Larva Migrans in humans, especially in children (DESPOMMIER, 2003; COELHO et al., 2004).

The transmission cycle of gastrointestinal parasites is influenced by several abiotic and biotic factors, which impact on their abundance into a given environment (MONTEIRO et al., 2016). Accordingly, the availability of infective stages in a highly contaminated habitat enhances the chance for paratenic (e.g., rodents) and accidental (e.g., humans) hosts to be exposed to the pathogens (THOMPSON \& CONLAN, 2011).

In these circumstances, understanding the dynamic of the infection is essential to plan control strategies. Besides experimental activities in controlled-laboratory conditions, the dynamic of the infection by parasites has been poorly studied in select areas, such insular regions, where confined animal population animals and pathogens may show a different behaviour. For instance, studies on gastrointestinal parasites in cats and rodents at the Fernando de Noronha Archipelago are scarce, although this archipelago has suffered over the last years from anthropic modification, which took to the introduction of exotic animal species, including cats and rodents (COSTA et al., 2012). Recently, few studies have been conducted in this area with T. gondii (SILVA et al., 2017), however lack information to others gastrointestinal parasites.

Therefore, because the scarce of data about gastrointestinal parasites and their implications on animals living in Fernando de Noronha Archipelago, the aim of this study was to assess the parasitism by gastrointestinal parasites in feral cats and rodents.

\section{Material and Methods}

\section{Ethical aspects}

This study approved by the Instituto Chico Mendes de Conservação da Biodiversidade - ICMBio (licence number 48994-3) and performed following the current legislation of the Brazilian College of Animal Experimentation.

\section{Study area}

The study was performed on August 2016 in the middle of winter of the Fernando de Noronha Archipelago (350'24" S and $\left.32^{\circ} 24^{\prime} 48^{\prime \prime} \mathrm{W}\right)$. The area is formed by the main island and other 21 secondary islands comprising a total area of $26 \mathrm{~km}^{2}$. The main island has about 3000 inhabitants, but every year may host until 50.000 tourists (IBGE, 2010). The local ecosystem is comprised by several native and exotic species of birds, reptiles, mammals, marine animals and several non-native species of arthropods.

\section{Sampling and laboratorial procedures}

Rodents were trapped using Tomahawk Live Traps (Gabisa Ltda., São Paulo, Brazil) that were placed at 17:00 pm and recovered at 06:00 am. All rodents were anesthetized with i.m. ketamine (Vetanarcol ${ }^{\oplus}$, Konig, Santana de Panaíba, SP, Brazil; 30 mg/kg) and xylazine (Xilazin ${ }^{\oplus}$, Syntec, Santana do Parnaíba, SP, Brazil; $2 \mathrm{mg} / \mathrm{kg}$ ), then, fecal samples were obtained.

Conversely, samples of cats were obtained after spontaneous defecation. A total of 67 faecal samples were collected, 37 from feral cats (Felis catus) and 30 from rodents (Rattus rattus, $\mathrm{n}=25$; Kerodon rupestris, $\mathrm{n}=05$ ). All samples were conserved into plastic tubes containing 10\% formalin solution until laboratory evaluation. Each sample was individually analysed through the FLOTAC technique (CRINGOLI et al., 2010). All cysts, eggs, oocysts and larvae were identified based on morphological features provided in Bowman et al. (2006) and Taylor et al. (2010).

\section{Data analysis}

Data were analysed by using the software InStat (GraphPad Software), with a significance level of $\mathrm{p}<0.05$.

\section{Results}

All samples analysed, scored positive for at least one gastrointestinal parasite species, and up to 17 parasite genera were identified. In particular, infections by trematodes, cestodes, nematodes and protozoa and were observed in 5.8\% (1/17), 17.8\% (3/17), $53 \%(9 / 17)$ and $23.5 \%(4 / 17)$, respectively (Table 1). Eggs and larvae of Ancylostoma sp., Strongyloides sp., Trichuris campanula and Toxocara cati were the parasites more frequently detected in feral cats. In rodents eggs, larvae and/or oocysts of Eimeria sp., Strongyloides sp. and Trichuris muris were parasites more frequently.

Co-infections were detected in $83.6 \%$ (56/67) fecal samples, in particular, $60.7 \%(34 / 56)$ and $39.2 \%(22 / 56)$ in the feral cats and rodents, respectively (Table 1 ).

\section{Discussion}

This study investigated, for the first time, the presence of gastrointestinal parasites in rodents and feral cats living at the Fernando de Noronha Archipelago, Brazil. 
Table 1. Gastrointestinal parasites in the fecal samples of feral cats and rodents from Fernando de Noronha archipelago, Brazil.

\begin{tabular}{|c|c|c|c|c|}
\hline \multirow{2}{*}{ Order / Family } & \multirow{2}{*}{ Species } & \multirow{2}{*}{ Parasite } & \multicolumn{2}{|c|}{ Positivity } \\
\hline & & & $\mathrm{AF}(\mathbf{n} / \mathrm{N})$ & RF (\%) \\
\hline \multirow[t]{9}{*}{ Carnivora/ Felidae } & Felis catus & Ancylostoma sp. & $35 / 37$ & 94.59 \\
\hline & & Ascarididae & $02 / 37$ & 5.40 \\
\hline & & Dipylidium caninum & $01 / 37$ & 2.70 \\
\hline & & Cystoisospora felis & $13 / 37$ & 35.00 \\
\hline & & Giardia sp. & $01 / 37$ & 2.70 \\
\hline & & Platynosomum factosum & $10 / 37$ & 27.00 \\
\hline & & Strongyloides sp. & $20 / 37$ & 54.00 \\
\hline & & Toxocara cati & $07 / 37$ & 19.00 \\
\hline & & Trichuris campanula & $18 / 37$ & 48.6 \\
\hline \multirow[t]{15}{*}{ Rodentia/ Muridae } & Rattus rattus & Ancylostomatidae & $25 / 25$ & 100.00 \\
\hline & & Ascarididae & $02 / 25$ & 8.00 \\
\hline & & Capillaria sp. & $07 / 25$ & 28.00 \\
\hline & & Eimeria sp. & $09 / 25$ & 36.00 \\
\hline & & Dipylidium sp. & $01 / 25$ & 4.00 \\
\hline & & Entamoeba sp. & $01 / 25$ & 4.00 \\
\hline & & Enterobius sp. & $02 / 25$ & 8.00 \\
\hline & & Giardia sp. & $03 / 25$ & 12.00 \\
\hline & & Hyminolepis nana & $06 / 25$ & 24.00 \\
\hline & & Nematospiroides dubius & $05 / 25$ & 20.00 \\
\hline & & Nippostrongylus brasiliensis & $03 / 25$ & 12.00 \\
\hline & & Strongyloides sp. & $10 / 25$ & 40.00 \\
\hline & & Taenia sp. & $07 / 25$ & 28.00 \\
\hline & & Toxocara sp. & $04 / 25$ & 16.00 \\
\hline & & Trichuris muris & $08 / 25$ & 32.00 \\
\hline \multirow[t]{4}{*}{ Rodentia/ Caviidae } & Kerodon rupestris & Ancylostomatidae & $03 / 05$ & 60.00 \\
\hline & & Capillaria sp. & $01 / 05$ & 20.00 \\
\hline & & Eimeria sp. & $04 / 05$ & 80.00 \\
\hline & & Strongyloides ratti & $03 / 05$ & 60.00 \\
\hline
\end{tabular}

AF- Absolute frequency; RF - Relative Frequency.

Data indicate that the level of parasitism in these "exotic" animals is higher than that observed in other studies performed in other insular areas (THOMPSON \& CONLAN, 2011). For instance, a prevalence of 53.5\% (15/28) and 76\% (76/100) were documented in feral cats from Christmas (Australia) and Baleares (Spain) islands (ADAMS et al., 2008; RAAB et al., 2016), whereas a positivity of $46.2 \%(30 / 65)$ was reported in rodents from the Santa Catarina island (Brazil) (KUHNEN et al., 2012). This suggests that animals living in the study areas are exposed to a high infective pressure.

Worthy of note, the majority of the parasite detected in this study are of medical concern (e.g., Ancylostoma sp. and T. cati), representing a threat for the public health. For example, Ancylostoma sp. were recorded in cats from Brazil (THOMPSON \& CONLAN, 2011), causing cutaneous Larva migrans syndrome in humans (BOWMAN et al., 2010). Another important parasite that deserves attention due the risk for humans are those of the Toxocara cati observed in this study in feral cats, and considered the responsible for visceral larva migrans (VLM), ocular Larva migrans (OLM) and cerebral Toxocariasis in humans (DESPOMMIER, 2003; FAN et al., 2015).

In addition, it is important to highlight the detection of Hymenolepis nana and Taenia sp. parasitizing rodents and humans, all of them of medical and veterinary concern (MOLINARO et al., 2009; GALAN-PUCHADES, 2015), were helminths that parasitize humans, which may cause diarrhea, abdominal pain, irritability and weight loss (MUEHLENBACHS et al., 2015).

On the other hand, $G$. duodenale causes serious problems to host health, due to the appearance of enteritis, which trigger enzymatic and morphological changes in intestinal loops (SMITH et al., 2007). It is interesting to note that based on molecular and phylogenetic evidence, $G$. duodenale is part of a complex genetic group, with genotypes A and B accounting for more than $80 \%$ of human infections (RYAN \& CACCIÒ, 2013).

In the present study, the sharing of parasites among different hosts suggests this phenomenon and may have important implications on the risk for human infections. For instance, data herein reported demonstrated the sharing of some parasite species, particularly, Entamoebidae among rodents, and humans, since data of the Surveillance Service of the island recorded frequently the parasitism by Endolimax nana in human native residents.

The presence of parasites on these hosts from the island may be a result of ecological events and their early introduction in this environment by conquestors. However, their perpetuation is favoured by several determinants factors such as inadequate facilities and inappropriate basic sanitation. Therefore, people living 
in this area are at risk of parasite infections due to the population of feral cats and rodents in the archipelago.

\section{References}

Adams PJ, Elliot AD, Algar D, Brazell RI. Gastrointestinal parasites of feral cats from Christmas Island. Aust Vet J 2008; 86(1-2): 60-63. PMid:18271830. http://dx.doi.org/10.1111/j.1751-0813.2007.00246.x.

Backhans A, Jacobson M, Hansson I, Lebbad M, Lambertz ST, Gammelgård E, et al. Occurrence of pathogens in wild rodents caught on Swedish pig and chicken farms. Epidemiol Infect 2013; 141(9): 1885-1891. PMid:23174339. http://dx.doi.org/10.1017/S0950268812002609.

Balassiano BCC, Campos MR, Menezes RCAA, Pereira MJS. Factors associated with gastrointestinal parasite infection in dogs in Rio de Janeiro, Brazil. Prev Vet Med 2009; 91(2-4): 234-240. PMid:19577316. http:// dx.doi.org/10.1016/j.prevetmed.2009.05.030.

Beugnet F, Bourdeau P, Chalvet-Monfray K, Cozma V, Farkas R, Guillot J, et al. Parasites of domestic owned cats in Europe: co-infestations and risk factors. Parasit Vectors 2014; 7(1): 291. PMid:24965063. http:// dx.doi.org/10.1186/1756-3305-7-291.

Blagburn BL, Lindsay DS, Vaughan JL, Rippey NS, Wright JC, Lynn $\mathrm{RC}$, et al. Prevalence of canine parasites based on fecal flotation. Comp Cont Educ Pract 1996; 18: 483-509.

Bowman DD, Lynn RC, Eberhard ML, Alcaraz A. Parasitologia veterinária de Georgis. 8. ed. São Paulo: Elsevier; 2006.

Bowman DD, Montgomery SP, Zajac AM, Eberhard ML, Kazacos KR. Hookworms of dogs and cats as agents of cutaneous larva migrans. Trends Parasitol 2010; 26(4): 162-167. PMid:20189454. http://dx.doi. org/10.1016/j.pt.2010.01.005.

Coelho LM, Silva MV, Dini CY, Giacon AA No, Novo NF, Silveira EP. Human toxocariasis: a seroepidemiological survey in schoolchildren of Sorocaba, Brazil. Mem Inst Oswaldo Cruz 2004; 99(6): 553-557. PMid:15558160. http://dx.doi.org/10.1590/S0074-02762004000600002.

Costa DGC, Marvulo MFV, Silva JSA, Santana SC, Magalhães FJR, Lima CD Fo, et al. Seroprovelence of Toxoplasma gondii in domestic and wild animals from the Fernando de Noronha, Brazil. J Parasitol 2012; 98(3): 679-680. PMid:22150091. http://dx.doi.org/10.1645/GE-2910.1.

Cringoli G, Rinaldi L, Maurelli MP, Utzinger J. FLOTAC: new multivalent techniques for qualitative and quantitative copromicroscopic diagnosis of parasites in animals and humans. Nat Protoc 2010; 5(3): 503-515. PMid:20203667. http://dx.doi.org/10.1038/nprot.2009.235.

Deplazes P, Eckert J, Mathis A, Samson-Himmelstjerna G, Zahner H. Parasitology in veterinary medicine. The Netherlands: Wageningen Academic Publishers; 2016.

Despommier D. Toxocariasis: clinical aspects, epidemiology, medical ecology, and molecular aspects. Clin Microbiol Rev 2003; 16(2): 265-272. PMid:12692098. http://dx.doi.org/10.1128/CMR.16.2.265-272.2003.

Fan CK, Holland CV, Loxton K, Barghouth U. Cerebral toxocariasis: silent progression to neurodegenerative disorders? Clin Microbiol Rev 2015; 28(3): 663-686. PMid:26062575. http://dx.doi.org/10.1128/ CMR.00106-14.
Galan-Puchades MT. Hymenolepis nana vs. Taenia solium life cycle. Parasite Immunol 2015; 37(8): 429. PMid:26216023. http://dx.doi. org/10.1111/pim.12204.

Instituto Brasileiro de Geografia e Estatística - IBGE. Censo Demográfico. Rio de Janeiro: IBGE; 2010. 270 p.

Kuhnen VV, Graipel ME, Pinto CJC. Differences in richness and composition of gastrointestinal parasites of small rodents (Cricetidae, Rodentia) in a continental and insular area of the Atlantic Forest in Santa Catarina state, Brazil. Braz J Biol2012; 72(3): 563-567. PMid:22990827. http://dx.doi.org/10.1590/S1519-69842012000300019.

Lóhmus M, Albihn A. Gastrointestinal pathogens in rodents overwintering in human facilities around Uppsala, Sweden. J Wildl Dis 2013; 49(3): 747-749. PMid:23778637. http://dx.doi.org/10.7589/2013-02-028.

Molinaro EM, Caputo LFG, Amendoeira MRR. Conceitos e métodos para formação de profissionais em laboratórios de saúde. vol. 4. Rio de Janeiro: Escola Politécnica de Saúde Joaquim Venâcio, Instituto Oswaldo Cruz; 2009. 290 p.

Monteiro MFM, Ramos RAN, Calado AMC, Lima VFS, Ramos ICN, Tenório RFL, et al. Gastrointestinal parasites of cats in Brazil: frequency and zoonotic risk. Rev Bras Parasitol Vet 2016; 25(2): 254257. PMid:27096530. http://dx.doi.org/10.1590/S1984-29612016019.

Muehlenbachs A, Bhatnagar J, Agudelo CA, Hidron A, Eberhard ML, Mathison BA, et al. Malignant Transformation of Hymenolepis nana in a Human Host. NEngl J Med 2015; 373(19): 1845-1852. PMid:26535513. http://dx.doi.org/10.1056/NEJMoa1505892.

Okyay P, Ertug S, Gultekin B, Onen O, Beser E. Intestinal parasites prevalence and related factors in school children, a western city sampleTurkey. BMC Public Health 2004; 4(2): 64. PMid:15615592. http:// dx.doi.org/10.1186/1471-2458-4-64.

Raab O, Greenwood S, Vanderstichel R, Gelens H. A cross-sectional study of Tritrichomonas foetus infection in feral and shelter cats in Prince Edward Island, Canada. Can Vet J2016; 57(3): 265-270. PMid:26933262.

Ryan U, Cacciò SM. Zoonotic potential of Giardia. Int J Parasitol 2013 43(12-13): 943-956. PMid:23856595. http://dx.doi.org/10.1016/j. ijpara.2013.06.001.

Saravanan M, Sarma K, Mondal DB, Ranjith Kumar M, Vijayakumar H. Concomitant infestation of Toxocara cati and Ancylostoma tubaeforme in a mongrel cat. J Parasit Dis 2016; 40(1): 205-207. PMid:27065627. http://dx.doi.org/10.1007/s12639-014-0451-5.

Silva JCR, Ferreira F, Dias RA, Ajzenberg D, Marvulo MFV, Magalhães FJR, et al. Cat-rodent Toxoplasma gondii Type II-variant circulation and limited genetic diversity on the Island of Fernando de Noronha, Brazil. Parasit Vectors 2017; 10(1): 220. PMid:28468666. http://dx.doi. org/10.1186/s13071-017-2150-4.

Smith HV, Cacciò SM, Cook N, Nichols RAB, Tait A. Cryptosporidium and Giardia as foodborne zoonoses. Vet Parasitol 2007; 149(1-2): 2940. PMid:17728067. http://dx.doi.org/10.1016/j.vetpar.2007.07.015.

Taylor MA, Coop RL, Wall RL. Parasitologia veterinária. 3. ed. Rio de Janeiro: Guanabara Koogan; 2010.

Thompson RC, Conlan JV. Emerging issues and parasite zoonoses in the SE Asian and Australasian region. Vet Parasitol 2011; 181(1): 6973. PMid:21570190. http://dx.doi.org/10.1016/j.vetpar.2011.04.025. 